\title{
The Effect of Subacute Exposure to Acrylamide on Femoral Bone Microstructure in Laboratory Mice
}

\author{
Anna Šarocká1*, Ramona Babosová ${ }^{1}$, Veronika Kováčová1, Patrik Šranko², \\ Radoslav Omelka ${ }^{2}$, Edyta Kapusta ${ }^{3}$, Zofia Goc ${ }^{3}$, \\ Grzegorz Formicki ${ }^{3}$, Monika Martiniaková ${ }^{1}$
}

${ }^{1}$ Department of Zoology and Anthropology, Faculty of Natural Sciences, Constantine the Philosopher University in Nitra, Slovak Republic

${ }^{2}$ Department of Botany and Genetics, Faculty of Natural Sciences, Constantine the Philosopher University in Nitra, Slovak Republic

${ }^{3}$ Department of Animal Physiology and Toxicology, Institute of Biology, Faculty of Geography and Biology, Pedagogical University in Krakow, Poland

Received: 20 May 2016

Accepted: 15 June 2016

\begin{abstract}
Acrylamide, a substituted unsaturated hydrocarbon, is often found in fried potatoes, flour, baby food, coffee, and olives. It is one of the most commonly consumed neurotoxins by humans. To date, its effect on bone structure has not been investigated in experimental animals. The aim of our manuscript was to analyze the impact of subacute exposure to acrylamide on the microscopic compact and trabecular bone tissue structures in laboratory mice. Adult male mice were divided into two groups. Animals from the experimental group (group $\mathrm{E}, \mathrm{n}=4$ ) were treated perorally with two doses of acrylamide $(1 \mathrm{mg} / \mathrm{kg} \mathrm{b.w.)} \mathrm{during} 24$ hours. The group without administration of AA served as a control (group $\mathrm{C}, \mathrm{n}=4$ ). Three hours after the second dose of AA (after 27 hours), mice were killed and their femurs were used for microscopic analysis. Our results demonstrate that subacute exposure to acrylamide causes an absence of the primary vascular radial bone tissue in pars posterior of the endosteal border. Mice from $\mathrm{E}$ group had more intact secondary osteons in pars medialis of the middle part of compact bone. Also, a few resorption lacunae were found in pars anterior of periosteal borders in these mice. Subacute exposure to AA significantly decreased the size of the primary osteon vascular canals $(\mathrm{P}<0.05)$ in compact bone tissue. In trabecular bone tissue, the values for bone volume, trabecular number, and bone surface were significantly increased in mice from the E group. In contrast, the value for trabecular separation was significantly decreased in these mice.
\end{abstract}

Keywords: acrylamide, femur, mouse, microstructure

*e-mail: sarocka.anna@gmail.com 


\section{Introduction}

Acrylamide (AA) is a monomer of polyacrylamide [1], the products of which occur in certain industrial processes [2]. AA is formed mainly from free asparagine and reducing sugars during high-temperature cooking [3]. High AA contents have been found in fried potatoes, flour, coffee, baby food, baking soda, and olives [4], and high consumption ranging from 23.86 to $56.83 \mu \mathrm{g} /$ day has been reported in European countries [5]. In China, AA has been detected in $43.7 \%$ of 144 food samples. This calculation makes AA one of the most commonly consumed neurotoxins by the human population. AA is also often absorbed during occupational exposure across the skin [2].

$\mathrm{AA}$ is a rodent carcinogen and also a probable human carcinogen (Class 2A) [6]. It has been reported to be neurotoxic and toxic to the reproductive system [7], and induces tumors in several organs in mice and rats [3]. AA can induce DNA strand breaks and lethal mutations [2].
In human erythrocytes (in vitro), AA increases hemolysis and lipid peroxidation [8], suggesting that this neurotoxin affects redox status in cells [9]. The reported oral LD50 value is $107 \mathrm{mg} / \mathrm{kg}$ body weight (b.w.) in mice.

AA appears to be metabolized into glycidamid, forming a DNA-reactive epoxide that implies genotoxicity [7] and can interact with other proteins at the cellular level [8]. To our knowledge, there are no studies describing its influence on bone structure. Therefore, the aim of the current study was to analyze in detail a microscopic structure of the compact and trabecular bone tissues in adult male mice after subacute exposure to AA.

\section{Experimental Procedures}

Our experiment was conducted on eight 12-week-old Swiss male mice obtained from the accredited experimental laboratory of the Pedagogical University in Krakow. The clinically healthy mice were randomly divided
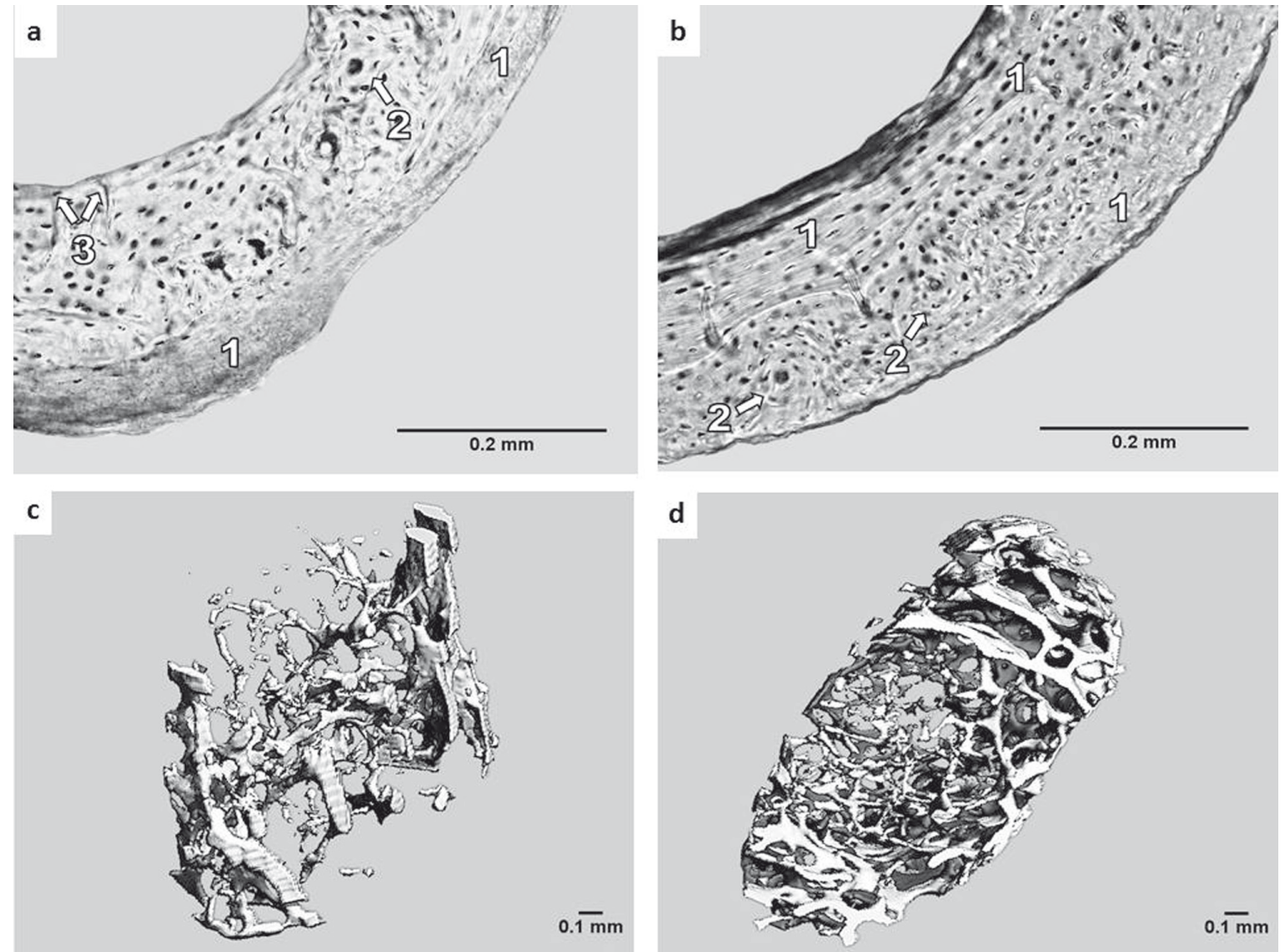

Fig. 1. Microstructure of compact and trabecular bone tissue in mice from groups $\mathrm{C}$ and $\mathrm{E}$.

a - Microscopic structure of compact bone tissue in mice from group $\mathrm{C}$

1 - non-vascular bone tissue

2 - the intact secondary osteon in the middle part of substantia compacta

3 - primary vascular radial bone tissue

$\mathrm{b}$ - Microscopic structure of compact bone tissue in mice from group $\mathrm{E}$

1 - non-vascular bone tissue

2 - intact secondary osteons in the middle part of substantia compacta

$\mathrm{c}$ - Representative reconstructed 3D image of trabecular bone in mice from group C

$\mathrm{d}$ - Representative reconstructed 3D image of trabecular bone in mice from group $\mathrm{E}$ 
into two groups of four animals each. In the experimental group (group $\mathrm{E}, \mathrm{n}=4$ ) young males were treated perorally with two doses of acrylamide ( $1 \mathrm{mg} / \mathrm{kg}$ b.w.) during 24 hours. AA was dissolved in physiological saline and was administered perorally to mice. The second group (group $\mathrm{C}, \mathrm{n}=4$ ) without AA administration served as a control. Peroral administration of AA was used in order to ensure the absorption of an entire dose of this neurotoxin into the organism. All the applied procedures were approved by the First Local Ethics Committee on Experiments on Animals in Krakow (resolution No. 175/2012).

Three hours after the second dose of AA (after 27 hours), mice were killed and their right femurs were used for histological analysis. Obtained femurs were macerated, degreased, and embedded in epoxy resin Biodur (Günter von Hagens, Heidelberg, Germany) according to the methodology of Martiniaková et al. [10]. Transverse thin sections $(70-80 \mu \mathrm{m})$ were prepared with sawing microtome (Leitz 1600, Leica, Wetzlar, Germany) and affixed to glass slides with Eukitt (Merck, Darmstadt, Germany) [11]. The qualitative histological characteristics of compact bone tissue were determined according to the classification systems of Enlow and Brown and Ricqlés, et al. [12-13]. The quantitative histological characteristics of the bone tissue were analyzed using Motic software images Plus 2.0 ML (Motic China Group Co., Ltd.) in all sides (anterior, posterior, medialis, lateralis) of thin sections. We measured area $\left(\mu \mathrm{m}^{2}\right)$, perimeter $(\mu \mathrm{m})$, and maximum and minimum diameters $(\mu \mathrm{m})$ of the primary osteon vascular canals, Haversian canals, and secondary osteons. The measured values were expressed as mean \pm standard deviation. Left femurs were used for microscopic analysis of trabecular bone tissue and also for measurements of cortical bone thickness. Morphometrical characteristics of trabecular bone tissue and cortical bone thickness were determined using microCT ( $\mu C T$ 50, Scanco Medical). $\mu C T$ studies were performed only on the distal femora to image trabecular bone morphometry. Trabecular bone was analyzed in a region of interest starting $1.2 \mathrm{~mm}$ from the end of the growth plate and extending $1.5 \mathrm{~mm}$. The follow- ing parameters were measured: bone volume (\%), trabecular number $(1 / \mathrm{mm})$, trabecular thickness $(\mathrm{mm})$, trabecular separation $(\mathrm{mm})$, and bone surface $\left(\mathrm{mm}^{2}\right)$. Cortical bone thickness was analyzed in a region of interest starting $5.2 \mathrm{~mm}$ from the end of the growth plate and extending $1.5 \mathrm{~mm}$ at the femoral midshaft.

The differences in quantitative characteristics of compact and trabecular bone tissues between mice from $\mathrm{C}$ and $\mathrm{E}$ groups were determined using T-test $(\mathrm{P}<0.05)$.

\section{Results and Discussion}

Mice from $\mathrm{C}$ group had the following compact bone microstructure. The inner layer surrounding the medullary cavity was formed by a zone of non-vascular bone tissue (in anterior, medial, and lateral views). In pars posterior we identified primary vascular radial bone tissue. This tissue was formed by branching or nonbranching vascular canals radiating from the bone marrow cavity or periosteum, which extended partially across the compacta. Some primary osteons were observed in the middle parts of substantia compacta (mainly in anterior and lateral views). Several secondary osteons were found in pars posterior of the central bone area. Non-vascular bone tissue was identified in pars medialis. The periosteal border was again composed of non-vascular bone tissue (Fig. 1a). Our findings from the qualitative histological analysis of compact bone tissue of mice correspond with previous studies $[12,14]$.

In mice from group $\mathrm{E}$, an absence of the primary vascular radial bone tissue in pars posterior of the endosteal border was evident. The endosteal border was formed by non-vascular bone tissue in all views (anterior, medial, lateral, and posterior) of thin section(s). Also, more intact secondary osteons in pars medialis of the middle parts of compact bone were observed in mice from the E group (Fig. 1b). A few resorption lacunae were identified in these mice in pars anterior of the periosteal border.

Table 1. Data of the primary osteon vascular canals, Haversian canals, and secondary osteons in male mice from groups E and C.

\begin{tabular}{|c|c|c|c|c|c|c|}
\hline Measured structures & Group & $\mathrm{n}$ & Area $\left(\mu \mathrm{m}^{2}\right)$ & Perimeter $(\mu \mathrm{m})$ & Max. diameter $(\mu \mathrm{m})$ & Min. diameter $(\mu \mathrm{m})$ \\
\hline \multirow{3}{*}{$\begin{array}{l}\text { Vascular canals of } \\
\text { primary osteons }\end{array}$} & $\mathrm{C}$ & 114 & $48.80 \pm 11.85$ & $25.35 \pm 3.14$ & $4.56 \pm 0.71$ & $3.40 \pm 0.53$ \\
\hline & $\mathrm{E}$ & 115 & $39.14 \pm 10.12$ & $22.34 \pm 2.99$ & $3.89 \pm 0.62$ & $3.18 \pm 0.47$ \\
\hline & \multicolumn{2}{|c|}{$\mathrm{T}$ - test } & $\mathrm{P}<0.05$ & $\mathrm{P}<0.05$ & $\mathrm{P}<0.05$ & $\mathrm{P}<0.05$ \\
\hline \multirow{3}{*}{ Haversian canals } & $\mathrm{C}$ & 13 & $32.48 \pm 6.59$ & $20.38 \pm 2.01$ & $3.50 \pm 0.42$ & $2.95 \pm 0.46$ \\
\hline & $\mathrm{E}$ & 18 & $31.97 \pm 7.53$ & $20.09 \pm 2.28$ & $3.40 \pm 0.42$ & $2.97 \pm 0.45$ \\
\hline & \multicolumn{2}{|c|}{$\mathrm{T}$ - test } & NS & NS & NS & NS \\
\hline \multirow{3}{*}{ Secondary osteons } & $\mathrm{C}$ & 13 & $439.15 \pm 189.22$ & $73.32 \pm 16.55$ & $12.72 \pm 2.75$ & $10.52 \pm 2.61$ \\
\hline & $\mathrm{E}$ & 18 & $370.78 \pm 115.23$ & $68.51 \pm 10.45$ & $11.96 \pm 1.99$ & $9.71 \pm 1.57$ \\
\hline & \multicolumn{2}{|c|}{ T- test } & NS & NS & NS & NS \\
\hline
\end{tabular}

n: number of measurements; NS: non-significant differences 
Table 2. Quantitative characteristics of trabecular bone tissue in adult mice from groups E and C.

\begin{tabular}{|c|c|c|c|c|c|c|}
\hline Group & $\mathrm{n}$ & BV/TV (\%) & Tb. N. $(1 / \mathrm{mm})$ & Tb. Th. $(\mathrm{mm})$ & Tb. Sp. $(\mathrm{mm})$ & Bs. $\left(\mathrm{mm}^{2}\right)$ \\
\hline C & 4 & $0.08 \pm 0.02$ & $3.97 \pm 0.45$ & 0.04 & $0.25 \pm 0.03$ & $14.75 \pm 5.29$ \\
\hline E & 4 & $0.13 \pm 0.01$ & $4.75 \pm 0.09$ & 0.04 & $0.20 \pm 0.01$ & $22.63 \pm 1.68$ \\
\hline T - test & & $\mathrm{P}<0.05$ & $\mathrm{P}<0.05$ & $\mathrm{NS}$ & $\mathrm{P}<0.05$ & $\mathrm{P}<0.05$ \\
\hline
\end{tabular}

n: number of measurements; NS: non-significant differences; BV/TV - bone volume; Tb. N. - trabecular number; Tb. Th. - trabecular thickness; Tb. Sp. trabecular separation; Bs. - bone surface

According to several authors [8-9, 15] AA increases the oxidative stress and peroxidation of the lipids. The oxidative stress causes an increased production of reactive oxygen species (ROS) [16], which enhance osteoclastic activity [17] and bone resorption [18]. On the other hand, hydrogen peroxide, as one ROS, has a crucial role in decreased differentiation of osteoblasts [19]. In general, reduced osteoblast differentiation and increased activity of osteoclasts jointly increase bone resorption and the subsequent formation of resorption lacunae. Therefore, it is assumed that observed differences in qualitative histological characteristics of compact bone between mice from $\mathrm{E}$ and $\mathrm{C}$ groups might be related to these mechanisms.

For the quantitative histological characteristics of compact bone tissue, 229 vascular canals of primary osteons, 31 Haversian canals, and 31 secondary osteons were measured. The results are summarized in Table 1. We have found that subacute exposure to AA significantly decreased the size of the primary osteon vascular canals $(\mathrm{P}<0.05)$. On the other hand, the values for all measured variables of Haversian canals and secondary osteons did not differ significantly between mice from $\mathrm{E}$ and $\mathrm{C}$ groups.

Primary osteon vascular canal constriction in mice from group $\mathrm{E}$ can be related to the adverse effects of AA on blood vessels. Alturfan et al. [15] documented the suppressive effect of AA on lipid peroxidation that can cause a hypoxia, which acts as a potent vasoconstrictor of blood vessels [20]. The decreased size of the primary osteon vascular canals could also be related to the ROS activity, because ROS increases the mineralization and calcification of blood vessels [16]. The results of quantitative analysis of trabecular bone tissue in both groups of mice are summarized in Table 2.

We have found that values for bone volume, trabecular number, and bone surface were significantly increased in mice from group E. On the other hand, the value for trabecular separation was significantly decreased in these mice. Representative reconstructed 3D images of trabecular bones in mice from the $\mathrm{C}$ and $\mathrm{E}$ groups are illustrated in Figures 1c and 1d, respectively. Our results also showed an insignificant effect of AA administration on cortical bone thickness in mice $(0.18 \pm 0.009 \mathrm{~mm}$ and $0.17 \pm 0.022$ $\mathrm{mm}$ in mice from $\mathrm{E}$ and $\mathrm{C}$ groups, respectively).

The remodelation of the trabecular bone can be affected by the amount of calcium in the blood [21]. According to Raju et al. [8], AA increases calcium concentration in the blood, which may be manifested by increased calcification of this bone.
The exact mechanism of AA effect on bone cells is not yet known. We suppose that AA could influence bone structure through the modification of signal pathways of osteoblastogenesis and/or osteoclastogenesis. Knowing detailed molecular mechanisms of all changes in bone cells cultured in the presence of AA is our next challenge.

\section{Conclusion}

Subacute peroral exposure to AA at the dose used in our study is manifested in substantia compacta by the absence of primary vascular radial bone tissue at the endosteal border. Also, it increases the number of intact secondary osteons, gives rise to several resorption lacunae, and decreases the size of the vascular canals of primary osteons. In trabecular bone tissue, subacute administration to AA significantly increases bone volume, trabecular number, and bone surface, and decreases trabecular separation. Our study provides the first information related to AA impact on bone structure in experimental animals.

\section{Acknowledgements}

This work was supported by the Slovak Research and Development Agency under contract No. SKPL-2015-0032. The study was also supported by the VEGA 1/0653/16 and KEGA 031UKF-4/2016 projects. The authors gratefully acknowledge the revision of the English text by Kim Dammers.

\section{References}

1. PARK J., KAMENDULIS L.M., FRIEDMAN M.A., KLAUNIG J.E. Acrylamide-Induced Cellular Transformation. Toxicol. Sci. 65 (2), 177, 2002.

2. LI J., LI D., YANG Y., XU T., LI P., HE D. Acrylamide induces locomotor defects and degeneration of dopamine neurons in Caenorhabditis elegans. J. Appl. Toxicol. 36 (1), 60, 2015.

3. PEDRESCHI F., MARIOTTI M.S., GRANBY K. Current issues in dietary acrylamide: formation, mitigation and risk assessment. J. Sci. Agric. 94 (1), 9, 2014.

4. FRIEDMAN M. Acrylamide: inhibition of formation in processed food and mitigation of toxicity in cells, animals, and humans. Food Funct. 6 (6), 1752, 2015. 
5. KOPAŃSKA M., LUKÁČ N., KAPUSTA E., FORMICKI G. Acrylamide Influence on Activity of Acetylcholinesterase, Thiol Groups, and Malondialdehyde Content in the Brain of Swiss Mice. J. Biochem. Mol. Toxicol. 29 (10), 472, 2015.

6. BELAND F.A., MELLICK P.W., OLSON G.R., MENDOZA M.C., MARQUES M.M., DOERGE D.R. Carcinogenicity of acrylamide in $\mathrm{B} 6 \mathrm{C} 3 \mathrm{~F}(1)$ mice and $\mathrm{F} 344 / \mathrm{N}$ rats from a 2-year drinking water exposure. Food Chem. Toxicol. 51, 149, 2013.

7. PARK H.R., KIM M.-S., KIM S.J., PARK M., KONG K.H., KIM H.S., KWACK S.J., KANG T.S., KIM S.H., KIM H.S., LEE J. Acrylamide induces cell death in neural progenitor cells and impairs hippocampal neurogenesis. Toxicol. Lett. 193 (1), 86, 2010.

8. RAJU J., ROBERTS J., TAYLOR M., PATRY D., CHOMYSHYN E., CALDWELL D., COOKE G., MEHTA R. Toxicological effects of short-term dietary acrylamide exposure in male F344 rats. Environ. Toxicol. Pharmacol. 39 (1), 85, 2015.

9. RODRÍGUEZ-RAMIRO I., MARTÍN M.Á., RAMOS S., BRAVO L., GOYA L. Olive oil hydroxytyrosol reduces toxicity evoked by acrylamide in human Caco- 2 cells by preventing oxidative stress. Toxicology. 288 (1-3), 43, 2011.

10. MARTINIAKOVÁ M., OMELKA R., GROSSKOPF B., SIROTKIN A. V., CHRENEK P. Sex-related variation in compact bone microstructure of the femoral diaphysis in juvenile rabbits. Acta Vet. Scand. 50, 15, 2008.

11. MARTINIAKOVÁ M., OMELKA R., JANCOVÁ A., STAWARZ R., FORMICKI G. Heavy metal content in the femora of yellow-necked mouse (Apodemus flavicollis) and wood mouse (Apodemus sylvaticus) from different types of polluted environment in Slovakia. Environ. Monit. Assess. $171(1-4), 651,2010$.

12. ENLOW D.H., BROWN S.O. Comparative histological study of fossil and recent bone tissues. Part I., Tex. J. Sci. 8, 405, 1956.
13. RICQLÉS A.J., MEUNIER F.J., CASTANET J., FRANCILLON-VIEILLOT H. Comparative microstructure of bone. Bone 3, Bone Matrix and Bone Specific Products. Hall BK. Boca Raton: CRC Press. 1991.

14. TREUTING P.M., DINTZIS S.M. Comparative Anatomy and Histology a Mouse and Human Atlas. Oxford, UK, Elsevier Inc. 2012.

15. ALTURFAN A.A., TOZAN-BECEREN A., SEHIRLI A.Ö., DEMIRALP E., SENER G., OMURTAG G. Z. Resveratrol ameliorates oxidative DNA damage and protects against acrylamide-induced oxidative stress in rats. Mol. Biol. Rep. 39 (4), 4589, 2012.

16. MODY N., PARHAMI F., SARAFIAN T.A., DEMER L.L. Oxidative stress modulates osteoblastic differentiation of vascular and bone cells. Free Radical Bio. Med. 31 (4), 509, 2001.

17. WAUQUIER F., LEOTOING L., COXAM V., GUICHEUX J., WITTRANT Y. Oxidative stress in bone remodelling and disease. Trends. Mol. Med. 15 (10), 468, 2009.

18. BAI X., LU D., LIU A., ZHANG Z., LI X., ZOU Z., ZENG W., CHENG B., LUO S. Reactive Oxygen Species Stimulates Receptor Activator of NF- $\mathrm{\kappa B}$ Ligand Expression in Osteoblast. J. Biol. Chem. 280 (17), 17497, 2005.

19. LIU A.L., ZHANG Z.-M., ZHU B.-F., LIAO Z.-H., LIU Z. Metallothionein protects bone marrow stromal cells against hydrogen peroxide-induced inhibition of osteoblastic differentiation. Cell. Biol. Int. 28 (12), 905, 2004.

20. SHWEIKI D., ITIN A., SOFFER D., KESHET E. Vascular endothelial growth factor induced by hypoxia may mediate hypoxia-initiated angiogenesis. Nature. 359 (6398), 843, 1992.

21. SIFFERT R.S. The role of alkaline phosphatase in osteogenesis. J. Exp. Med. 93, 415, 1951. 
